Volume 4 Nomor 2 Ed. Desember 2018 : page 140-152

p-ISSN: 2460-805X e-ISSN : 2550-0295

DOI : 10.24252/iqtisaduna.v4i2.5770

\title{
Pengaruh Usability, Information dan Service Interaction terhadap Minat Beli pada Pasar Virtual
}

\author{
Rodame Monitorir Napitupulu \\ IAIN Padangsidimpuan \\ Jl. H. Tengku Rizal Nurdin Km. 4.5 Sihitang. \\ Kota Padangsidimpuan - Sumatera Utara \\ E-mail : rodamenapitupulu@iain-padangsidimpuan.ac.id
}

Diterima: 16 Agustus 2018; Direvisi: 3 September 2018; Diterbitkan: 28 Desember 2018

\begin{abstract}
Abstrak,
Keberadaan internet secara nyata telah memampukan konsumen melakukan transaksi pembelian produk dari mana pun dan kapan pun. Hal tersebut mengubah pola belanja masyarakat di Indonesia dari belanja langsung ke toko menjadi belanja melalui website. Muslimarket.com adalah salah satu website belanja online (e-commerce) muslim terlengkap yang ada di Indonesia. Ketatnya persaingan e-commerce menuntut muslimarket.com harus mengoptimalkan penggunaan website sebagai media pemasaran online (e-marketing) sehingga mampu meningkatkan minat beli masyarakat guna meningkatkan bisnis syariah di Indonesia. Itulah sebabnya penelitian ini bertujuan untuk mengetahui pengaruh usability (kegunaan), information (informasi) dan service interaction interaksi layanan terhadap minat beli pada muslimarket.com. Penelitian ini menggunakan pendekatan kuantitatif dimana data primer diperoleh dengan penyebaran kuesioner elektronik (e-questionnaire) dengan instrumen Webqual 4.0, melalui media sosial dengan jumlah sampel sebanyak 100 orang yang tersebar di seluruh Indonesia. Berdasarkan hasil analisis regresi berganda, baik usability, information dan service interaction secara bersama-sama berpengaruh terhadap minat beli pada muslimarket.com. Namun, secara parsial, hanya information yang tidak berpengaruh terhadap minat beli pada muslimarket.com.
\end{abstract}

Kata Kunci: Webqual 4.o, website, e-commerce, minat beli

\begin{abstract}
,
Internet has changed the way consumer buying products. They now buy products through website. Muslimarket.com is one of the most complete e-commerce for Muslim product in Indonesia. The tight competition of e-commerce demanding muslimarket.com to optimized website as its e-marketing in order to improve buying interest so that the sharia business can also able to increase. The aim of this research is to know effect of usability, information and service interaction to buying intense through website. This research use quantitative approach. The three independent variables (usability, information and service interaction) built based on Webqual 4.o. The sample is 100 respondents that spread all over Indonesia. Based on the multiple linear regression, all independent variable: usability, information and service interaction have significant positive effect on buying interest at muslimarket.com. But partially, only information has not significant positive effect on buying interest at muslimarket.com.
\end{abstract}

Keywords: Webqual 4.0, website, e-commerce, purchasing interest 


\section{PENDAHULUAN}

Kehidupan manusia saat ini sulit dipisahkan dari teknologi informasi dan internet. Dapat dikatakan bahwa seluruh aspek dalam kehidupan manusia kini bergantung pada seberapa cepat manusia mampu memperoleh informasi. Hal tersebut bukan hanya terjadi di Negara-negara maju seperti Jepang, Cina dan Amerika tetapi juga terjadi di Indonesia. Segala aktivitas kini tidak terlepas dari penggunaan internet. Internet menyediakan infrastruktur teknis yang memampukan kita online dan terhubung dengan masyarakat dunia dengan mengakses world wide web (www) dan saat menemukan apa yang dibutuhkan, kita bahkan dapat memesan barang atau jasa tersebut melalui website.

Keberadaan internet secara nyata telah memampukan konsumen melakukan transaksi pembelian produk atau jasa dari mana pun dan kapan pun. Internet telah mendobrak batasan ruang dan waktu. Tentu saja hal tersebut menyebabkan terjadinya perubahan pola belanja masyarakat di Indonesia dari belanja langsung ke toko menjadi belanja online melalui website. Pengguna internet dunia per 31 Desember 2017 mencapai 2.119.060.152 orang dimana 48,7 \% dari total pengguna internet dunia tersebut berasal dari Asia. Di Asia sendiri, Indonesia adalah Negara dengan jumlah pengguna internet tertinggi ke-3 setelah Cina dan India.

Gambar 1. Pengguna Internet Berdasarkan Negara Asal (orang)

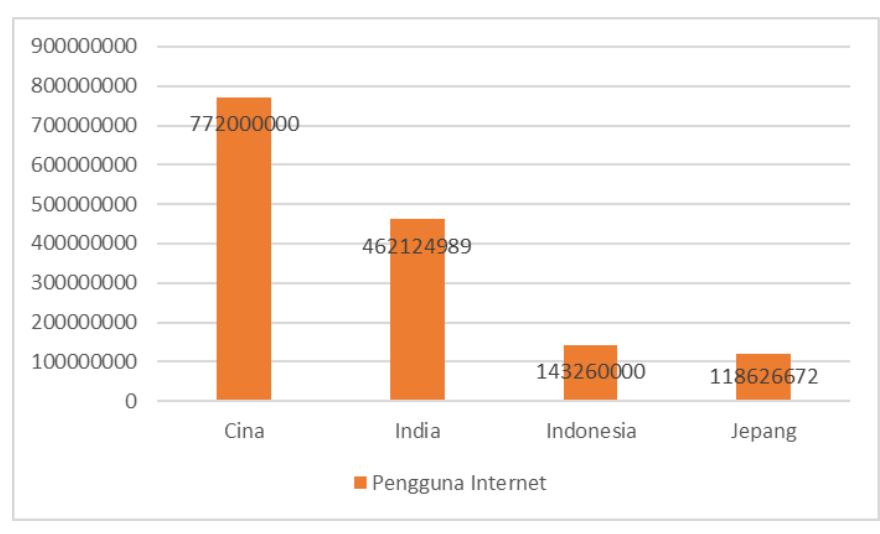

Berdasarkan hal tersebut, maka dapat dikatakan bahwa penetrasi internet di Indonesia cukup tinggi. Hal tersebut tentu akan sejalan dengan peningkatan transaksi belanja online melalui website di Indonesia. Semua bidang bisnis kini melakukan perubahan pemasaran produk atau jasanya yaitu pemasaran elektronik (e-marketing). Website adalah salah satu media yang sangat baik dalam e-marketing. Perusahaan dalam berbagai bidang bisnis kini membangun website dalam memasarkan produk atau jasanya termasuk bisnis syariah. 
Proses pembelian dan penjualan produk atau jasa antara kedua belah pihak melalui internet dikenal dengan istilah e-commerce. Menurut Laudon dan Carol (2009), e-commerce adalah penggunaan internet dan website untuk bertransaksi bisnis. Sedangkan marketplace adalah istilah untuk fasilitator belanja online yang tidak memiliki inventarisasi barangnya sendiri. Dengan berbagai kesibukan masyarakat saat ini, bukan hanya masyarakat di kota besar saja tetapi juga seluruh wilayah hingga ke daerah mengalami kesulitan dalam membeli produk atau jasa langsung ke toko maka pelaku e-commerce maupun marketplace akan sangat berperan penting dalam pemenuhan kebutuhan masyarakat. Rata-rata pertumbuhan marketplace mendekati angka $100 \%$ sedangkan e-commerce mancapai angka $289 \%$. Dapat disimpulkan bahwa pertumbuhan marketplace dan pelaku e-commerce di Indonesia sangat besar dan meningkat pesat.

Muslimarket.com adalah salah satu website belanja online muslim yang ada di Indonesia. Muslimarket.com merupakan website belanja online muslim terlengkap yang menyediakan berbagai kebutuhan seorang muslim mulai dari fashion, perabotan rumah tangga, kesehatan \& kecantikan, gaya hidup, tas, sepatu, aksesoris, kebutuhan anak \& bayi, batik dan perlengkapan ibadah. Selain itu muslimarket.com juga memberikan pelayanan bebas ongkos kirim dengan berbagai fasilitas pembayaran baik transfer maupun COD (cash on delivery) sehingga dapat memudahkan konsumen dalam melakukan transaksi pembelian.

Muslimarket.com memiliki nama yang mudah diingat. Selain itu, dengan mendengar nama muslimarket.com sebenarnya masyarakat yang memahami artinya sudah dapat membayangkan barang apa saja yang ditawarkan didalamnya, terlebih lagi ada kata 'muslim' yang menggambarkan bahwa semua kebutuhan seorang muslim dapat dibeli melalui website muslimarket.com. Itulah sebabnya keberadaan muslimarket.com di Indonesia seharusnya menjadi e-commerce berbasis syariah terbaik di Indonesia, sebagai negara dengan mayoritas penduduk muslim tertinggi di dunia. Sayangnya, pada hasil pengamatan awal peneliti dengan wawancara pada beberapa pengguna internet yang pernah melakukan pembelian produk melalui muslimarket, terdapat kekecewaan terutama karena lambatnya respon dalam melayani konsumen. Hal ini mengindikasikan bahwa website muslimarket belum sepenuhnya optimal dalam melayani kebutuhan konsumen.

Selain itu, banyaknya pelaku e-commerce dan marketplace di Indonesia yang juga memberikan penawaran produk seperti muslimarket.com menjadi penyebab tingginya persaingan $e$-commerce dan marketplace. Pelaku e-commerce maupun marketplace berbasis syariah bersaing ketat dengan pelaku e-commerce maupun marketplace non syariah. Itulah sebabnya website belanja online muslim seperti muslimarket.com harus meningkatkan dan memberdayakan website sebagai media pemasaran online yang efektif sehingga dapat 
meningkatkan jumlah konsumennya. Muslimarket.com harus menampilkan website yang menarik dan mudah digunakan dan harus dapat menghilangkan ketidakbenaran informasi, ketertinggalan informasi, navigasi yang tidak sesuai, link rusak. Selain itu, harus mampu menjamin keamanan bertransaksi keuangan dan kecepatan respon dalam melayani konsumen. Itulah sebabnya, mengetahui pengaruh usability, information dan service interaction terhadap minat beli pada muslimarket.com sebagai $e$-commerce berbasis syariah di Indonesia menjadi penting untuk dilakukan baik secara parsial maupun secara simultan.

\section{TINJAUAN TEORITIK}

\section{Kualitas Website}

Konsep kualitas harus bersifat menyeluruh, baik produk maupun prosesnya (Dorothea, 2004). Kualitas produk meliputi kualitas bahan baku dan barang jadi sedangkan kualitas proses meliputi segala sesuatu yang berhubungan dengan proses produksi perusahaan manufaktur dan proses penyediaan jasa atau pelayanan perusahaan jasa. Itulah sebabnya kualitas sudah seharusnya dibangun sejak awal mulai dari penerimaan input hingga menghasilan output bagi pelanggannya. Website adalah keseluruhan halaman-halaman web yang terdapat dalam sebuah domain yang mengandung informasi (Rahmat, 2010). Oleh karena itu kualitas website adalah kualitas dari sebuah website mulai dari input hingga output yang dirasakan pelanggan secara menyeluruh pada semua halaman web yang terdapat pada domain yang mengandung berbagai informasi yang dibutuhkan pelanggan. Kualitas website harus dipertimbangkan sebagai faktor penting dalam bisnis online (Sam \& Tahir, 2009). Hal tersebut karena kualitas website akan memengaruhi kepuasan konsumen, intensitas pengguna dan pemilihan website untuk melakukan transaksi di masa yang akan datang (Delone \& McLean, 2003).

\section{Webqual 4.o}

Adapun Webqual 4.0 menilai kualitas website dengan dilihat dari 3 kategori yaitu : usability, information quality dan service interaction quality (Barnes \& Vidgen, 2002). Webqual 4.0 adalah penyempuranan dari Webqual 1.0, Webqual 2.0 dan Webqual 3.0 sehingga Webqual 4.0 adalah alat analisis kualitas website yang terbaru dibandingkan ketiga sebelumnya. Berikut adalah kategori dan pertanyaan-pertanyaan pada Webqual 4.0: 
Tabel 1. Kategori dan Pertanyaan pada Webqual 4.0

\begin{tabular}{|c|c|}
\hline Kategori & Pertanyaan-Pertanyaan pada Webqual 4.o \\
\hline Usability (kegunaan) & $\begin{array}{l}\text { 1. Saya mendapati website mudah untuk dipelajari } \\
\text { dan dioperasikan } \\
\text { 2. Interaksi saya dengan website jelas dan dapat } \\
\text { dipahami } \\
\text { 3. Saya mendapati website mudah dinavigasikan } \\
\text { 4. Saya mendapati website mudah untuk digunakan } \\
\text { 5. Website memiliki tampilan yang atraktif } \\
\text { 6. Website memiliki desain yang sesuai } \\
\text { 7. Website mengandung nilai kompetensi (memiliki } \\
\text { daya saing) } \\
\text { 8. Website mampu menciptakan pengalaman yang } \\
\text { positif bagi saya }\end{array}$ \\
\hline Information (informasi) & $\begin{array}{l}\text { 9. Menyediakan informasi yang akurat } \\
\text { 10. Menyediakan informasi yang dapat dipercaya } \\
\text { 11. Menyediakan informasi yang tepat waktu } \\
\text { 12. Menyediakan informasi yang relevan } \\
\text { 13. Menyediakan informasi yang mudah dipahami } \\
\text { 14. Menyediakan informasi yang terperinci } \\
\text { 15. Menyajikan informasi dengan format yang sesuai }\end{array}$ \\
\hline $\begin{array}{l}\text { Service Interaction } \\
\text { (interaksi layanan) }\end{array}$ & $\begin{array}{l}\text { 16. Memiliki reputasi yang baik } \\
\text { 17. Terasa aman dalam menyelesaikan berbagai } \\
\text { transaksi } \\
\text { 18. Data pribadi terjaga } \\
\text { 19. Menciptakan rasa personalisasi } \\
\text { 20. Menyampaikan rasa kebersamaan } \\
\text { 21. Membuat semakin mudah berkomunikasi dengan } \\
\text { perusahaan } \\
\text { 22. Saya merasa yakin bahwa barang atau jasa yang } \\
\text { dikirim sesuai dengan yang dijanjikan }\end{array}$ \\
\hline
\end{tabular}

\section{Minat Beli}

Minat beli sering juga disebut sebagai niat pembelian. Dalam melakukan suatu niat pembelian, konsumen dapat membuat hingga enam sub-decision diantaranya: pilihan produk, pilihan merek, pilihan penjual, jumlah pembelian, waktu pembelian dan metode pembayaran (Kotler dan Keller, 2012). Minat beli (niat beli) terhadap suatu produk timbul karena adanya dasar kepercayaan terhadap produk yang diiringi dengan kemampuan untuk membeli produk (Simamora, 2011). Selain itu, minat beli terhadap suatu produk juga dapat terjadi dengan adanya pengaruh dari orang lain yang dipercaya oleh calon konsumen. Minat beli juga timbul apabila seseorang sangat tertarik terhadap berbagai informasi seputar produk 
yang diperoleh melalui iklan, pengalaman orang lain yang telah menggunakannya dan kebutuhan mendesak terhadap produk tersebut.

Minat memiliki sifat dan karakter khusus sebagai berikut (Husein, 2010):

1. Minat bersifat pribadi (individual), ada perbedaan antara minat seseorang dan orang lain.

2. Minat menimbulkan efek diskriminatif.

3. Erat hubungannya dengan motivasi, memengaruhi dan dipengaruhi motivasi.

4. Minat merupakan sesuatu yang dipelajari, bukan bawaan lahir dan dapat berubah tergantung pada kebutuhan, pengalaman dan mode.

Minat beli dapat diidentifikasi melalui indikator-indikator sebagai berikut (Ferdinand, 2006):

1. Minat transaksional, yaitu kecenderungan seseorang untk membeli produk.

2. Minat referensial, yaitu kecenderungan seseorang untuk mereferensikan produk kepada orang lain.

3. Minat preferensial, yaitu minat yang menggambarkan perilaku seseorang yang memiliki preferensi utama pada produk tersebut. Preferensi ini hanya dapat diganti jika terjadi sesuatu dengan produk preferensinya.

4. Minat eksploratif, minat ini menggambarkan perilaku seseorang yang selalu mencari informasi mengenai produk yang diminatinya dan mencari informasi untuk mendukung sifat-sifat positif dari produk tersebut.

Model Webqual 4.o terhadap minat beli diilustrasikan dalam gambar berikut,

Gambar 2. Model webqual 4.o terhadap Minat Beli

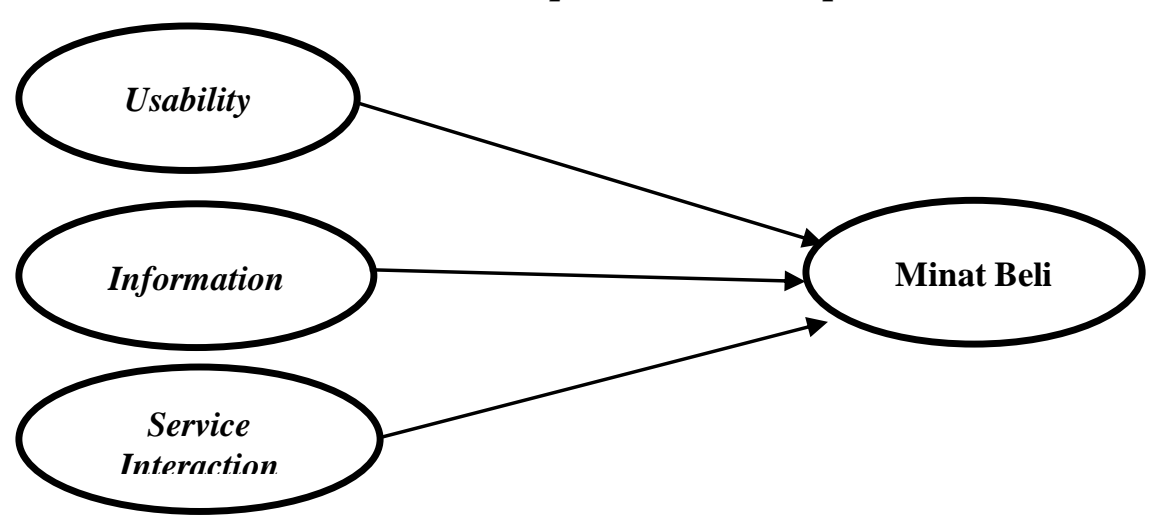

\section{METODE PENELITIAN}

Langkah-langkah atau tahapan pelaksanaan penelitian dimulai dengan penetapan jumlah sampel dengan menggunakan rumus Slovin. Sampel pada penelitian berjumlah 100 
orang dimana teknis pengambilan sampel dilakukan dengan purposive sampling (dengan kriteria tertentu). Khusus untuk penelitian di internet ditambahkan dengan screened sampling dimana teknik tersebut menambahkan beberapa persyaratan yang berfungsi untuk membatasi misalnya: demografi, usia, pendidikan, penghasilan dan lain-lain (Sarwono, 2006). Teknik penyebaran kuesioner elektronik dilakukan melalui media sosial seperti facebook dan Whatsapp. Setelah data terkumpul yaitu 100 responden lalu hasilnya secara otomatis dapat ditampilkan ke dalam Microsoft Excel.

Semua pertanyaan pada kuesioner elektronik kemudian diuji validitas dan reliabilitasnya. Kemudian dilanjutkan dengan uji asumsi klasik berupa uji normalitas, uji multikolinearitas, uji heteroskedastisitas. Pada penelitian ini tidak dilakukan uji otokorelasi karena data pada penelitian ini bersifat cross-sectiona (dalam waktu tertentu). Uji Normalitas tujuannya adalah untuk menguji data penelitian baik variabel dependen maupun independen telah terdistribusi normal dengan menggunakan Kolmogrov-Smirnov pada taraf signifikan 0,05. Lalu dilanjutkan dengan uji multikolinearitas untuk melihat adanya hubungan linear sempurna di antara variabel independen dengan melihat nilai VIF (Variance Inflation Factor). Sedangkan uji heteroskedastisitas digunakan untuk mengetahui ada tidaknya penyimpangan data. Dan uji otokorelasi dilakukan dengan melihat hasil uji Durbin-Watson (DW) (Sugiono dan Susanto, 2015).

Adapun tahapan lain yang juga penting dalam penelitian ini adalah pengujian hipotesis. Uji hipotesis digunakan untuk mengukur seberapa besar pengaruh variabel independen terhadap variabel dependen. Menurut Setiawan dan Kusrini (2010), nilai R² yang mendekati satu menunjukkan bahwa variabel-variabel independen memberikan hampir semua informasi yang dibutuhkan untuk memprediksi variasi variabel dependen. Sementara itu, untuk mengetahui apakah ada variabel independen pada model regresi yang berpengaruh secara parsial maka dilihat dari hasil uji t. Kaidah pengunjian untuk menguji secara parsial yaitu jika thitung lebih kecil atau sama dengan $\mathrm{t}$ tabel maka Ho diterima dan Ha ditolak dan jika thitung lebih besar atau sama dengan t table maka Ho ditolak dan Ha diterima (Siregar, 2014). Dan untuk mengetahui pengaruh semua variabel independen terhadap variabel dependen maka digunakanlah uji $\mathrm{F}$, uji ini dilakukan dengan syarat bila $\mathrm{F}_{\text {hitung }}<\mathrm{F}_{\text {tabel }}$ maka $\mathrm{H}_{\mathrm{o}}$ diterima dan $\mathrm{H}_{\mathrm{a}}$ ditolak, bila $\mathrm{F}_{\text {hitung }}>\mathrm{F}_{\text {tabel }}$ maka $\mathrm{H}_{\mathrm{o}}$ ditolak dan $\mathrm{H}_{\mathrm{a}}$ diterima. Semua tahapan uji dan analisis dilakukan dengan bantuan SPSS.

Analisis regresi berganda digunakan untuk mengetahui pengaruh dari variabel usability (X1), information (X2) dan service interaction $\left(\mathrm{X}_{3}\right)$ terhadap minat beli (Y), dengan persamaan regresi berganda sebagai berikut : 
Dimana :

$$
Y=\beta 0+b 1 X 1+b 2 X 2+b 3 X 3+e
$$

$$
\begin{array}{ll}
\mathrm{Y} & =\text { Variabel dependen (Minat Beli) } \\
\mathrm{a} & =\text { Konstanta } \\
\mathrm{b} 1 ; \mathrm{b} 2 ; \mathrm{b} 3 & =\text { Koefisien regresi } \\
\mathrm{X} 1 & =\text { Usability } \\
\mathrm{X}_{2} & =\text { Information } \\
\mathrm{X}_{3} & =\text { Service Interaction } \\
\mathrm{E} & =\text { error }
\end{array}
$$

\section{HASIL DAN PEMBAHASAN}

\section{Hasil Uji Validitas dan Reliabilitas}

Uji validitas bertujuan untuk mengetahui sejauh mana kuesioner elektronik dapat mengukur apa yang diinginkan. Untuk mengukur validitas digunakan korelasi product

\begin{tabular}{|c|c|c|c|c|}
\hline Variabel & Indikator & r hitung & Nilai Kritis & Keterangan \\
\hline \multirow{8}{*}{ Usability (X1) } & U1 & 0,828 & \multirow{8}{*}{ o, 1654} & Valid \\
\hline & U2 & 0,769 & & Valid \\
\hline & U3 & 0,721 & & Valid \\
\hline & $\mathrm{U}_{4}$ & 0,788 & & Valid \\
\hline & U5 & 0,627 & & Valid \\
\hline & U6 & 0,287 & & Valid \\
\hline & $\mathrm{U}_{7}$ & 0,327 & & Valid \\
\hline & U8 & 0,681 & & Valid \\
\hline \multirow{7}{*}{ Information (X2) } & I1 & 0,841 & \multirow{7}{*}{0,1654} & Valid \\
\hline & I2 & 0,680 & & Valid \\
\hline & I3 & 0,701 & & Valid \\
\hline & I4 & 0,641 & & Valid \\
\hline & I5 & 0,624 & & Valid \\
\hline & I6 & 0,617 & & Valid \\
\hline & I7 & 0,846 & & Valid \\
\hline \multirow{7}{*}{ Service Interaction $\left(\mathrm{X}_{3}\right)$} & SI1 & 0,456 & \multirow{7}{*}{0,1654} & Valid \\
\hline & SI2 & 0,466 & & Valid \\
\hline & SI3 & 0,383 & & Valid \\
\hline & SI4 & 0,383 & & Valid \\
\hline & SI5 & 0,235 & & Valid \\
\hline & SI6 & 0,366 & & Valid \\
\hline & SI7 & 0,602 & & Valid \\
\hline \multirow{5}{*}{ Minat Beli (Y) } & M1 & 0,248 & \multirow{5}{*}{0,1654} & Valid \\
\hline & M2 & 0,352 & & Valid \\
\hline & M3 & 0,228 & & Valid \\
\hline & M4 & 0,498 & & Valid \\
\hline & M5 & 0,604 & & Valid \\
\hline
\end{tabular}
moment Pearson. Jika korelasi product moment Pearson masing-masing pertanyaan dengan skor total menghasilkan nilai $r$ hitung $>0,1654(n=98)$, maka item pertanyaan tersebut dinyatakan valid. Berdasarkan uji validitas dengan bantuan SPSS, seluruh pertanyaan pada variabel penelitian dalam kuesioner elektronik yang dibagikan pada 100 responden menunjukkan bahwa nilai $r$ hitung lebih besar dari o,1654. Artinya seluruh pertanyaan dinyatakan valid.

Tabel 2. Uji Validitas Indikator Variabel Penelitian 
Sementara itu, berdasarkan uji reliabilitas bertujuan untuk mengetahui sejauh mana kuesioner elektronik dapat dipercaya atau dapat diandalkan. Diketahui bahwa semua pertanyaan dalam kuesioner elektronik yang dibagikan kepada 100 responden sudah reliabel dimana nilai Cronbach's Alpha yang diperoleh sebesar 0,916 atau 91.6\% sehingga dinyatakan reliabel.

Tabel 3. Uji Realibilitas Indikator Variabel Penelitian

\begin{tabular}{|c|c|c|}
\hline Variabel & Cronbach's Alpha & Keterangan \\
\hline Usability (X1) & \multirow{4}{*}{0,916} & Reliabel \\
\hline Information (X2) & & Reliabel \\
\hline Service Interaction $\left(\mathrm{X}_{3}\right)$ & & Reliabel \\
\hline Minat Beli (Y) & & Reliabel \\
\hline
\end{tabular}

\section{Hasil Uji Asumsi Klasik}

Uji normalitas bertujuan untuk mengetahui apakah data penelitian terdistribusi normal. Berdasarkan Tabel 4, dapat dilihat bahwa nilai Kolmogrov-Smirnow $Z$ diatas dari 0,05. Jika nilai Kolmogrov-Smirnow $Z$ diatas dari 0,05 maka data terdistribusi normal. Seluruh data dalam penelitian ini terdistribusi normal.

Tabel 4. Uji Normalitas dengan Kolmogorov-Smirnov Z

\begin{tabular}{|c|c|c|c|c|c|}
\hline & & Usability & Information & $\begin{array}{c}\text { Service } \\
\text { Interaction }\end{array}$ & Minat Beli \\
\hline \multicolumn{2}{|l|}{$\mathbf{N}$} & 100 & 100 & 100 & 100 \\
\hline \multirow{2}{*}{$\begin{array}{l}\text { Normal } \\
\text { Parametersa,,b }\end{array}$} & Mean & 29.9 & 26.42 & 24.41 & 18.48 \\
\hline & Std. Deviation & 4.941 & 4.217 & 4.557 & 3.953 \\
\hline \multirow{3}{*}{$\begin{array}{l}\text { Most Extreme } \\
\text { Differences }\end{array}$} & Absolute & 0.095 & 0.214 & 0.098 & 0.11 \\
\hline & Positive & 0.095 & 0.214 & 0.098 & 0.052 \\
\hline & Negative & -0.095 & -0.136 & -0.067 & -0.11 \\
\hline \multicolumn{2}{|c|}{ Kolmogorov-Smirnov Z } & 0.954 & 2.139 & 0.985 & 1.097 \\
\hline \multicolumn{2}{|c|}{ Asymp. Sig. (2-tailed) } & 0.322 & 0.273 & 0.286 & 0.18 \\
\hline
\end{tabular}

Selanjutnya setelah data tersebar secara normal maka dilanjutkan dengan uji multikolinearitas. Berdasarkan uji multikolinearitas pada Tabel 5, diketahui bahwa nilai VIF berada di bawah 5, jika nilai VIF berada di bawah 5 maka tiap-tiap variabel independen dalam penelitian ini yaitu usability (USE), information (INF) dan service interaction (SER) terbebas dari masalah multikolinieritas. 
Tabel 5. Uji Multikolinearitas

\begin{tabular}{lcc}
\hline Model & \multicolumn{2}{c}{ Collinearity Statistics } \\
\cline { 2 - 3 } & Tolerance & VIF \\
\hline USE & 0.497 & 2.013 \\
\hline INF & 0.471 & 2.122 \\
\hline SER & 0.559 & 1.788 \\
\hline
\end{tabular}

Berdasarkan hasil uji heteroskedastisitas pada Gambar 3, dengan menggunakan scatterplot, diketahui bahwa diagram pencar residual tidak membentuk pola tertentu. Pada penelitian ini, diagram pencar residual ternyata tidak membentuk pola tertentu. Oleh karena itu, dapat disimpulkan bahwa tidak terdapat masalah heteroskedastisitas.

Gambar 3. Hasil Uji Heteroskedastisitas

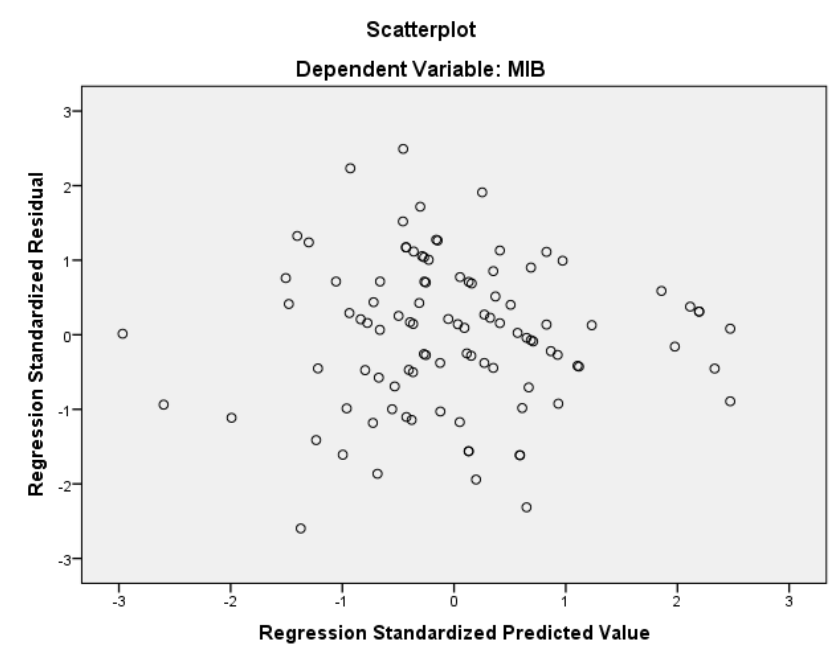

\section{Hasil Analisis Regresi Berganda}

Berdasarkan hasil analisis regresi berganda diketahui persamaan regresi yang terbentuk adalah :

$$
\mathrm{MIB}=2,134+0,05 \mathrm{OUSE}+0,237 \mathrm{INF}+0,353 \mathrm{SER}
$$

Persamaan yang terbentuk tersebut dapat dijelaskan bahwa jika seluruh variabel independen dianggap konstan atau o maka minat beli pada muslimarket.com 2,134. Jika information (INF) naik sebesar 1 maka minat beli pada muslimarket.com naik sebesar 0,237. Jika service interaction (SER) naik sebesar 1 maka minat beli pada muslimarket.com naik sebesar 0,353 . Sedangkan usability (USE) tidak berpengaruh terhadap minat beli pada 
muslimarket.com dibuktikan dengan $\mathrm{t}$ hitung $<\mathrm{t}$ tabel $(0,558<1,661)$. Selengkapnya pada Tabel 7.

Tabel 7. Hasil Olahan Analisis Regresi Berganda

\begin{tabular}{|c|c|c|c|c|c|c|}
\hline \multirow{2}{*}{\multicolumn{2}{|c|}{ Model }} & \multicolumn{2}{|c|}{ Unstandardized Coefficients } & \multirow{2}{*}{$\begin{array}{c}\text { Standardized } \\
\text { Coefficients } \\
\text { Beta }\end{array}$} & \multirow[t]{2}{*}{$\mathbf{t}$} & \multirow[t]{2}{*}{ Sig. } \\
\hline & & B & Std. Error & & & \\
\hline \multirow{4}{*}{$\mathbf{1}$} & (Constant) & 2.131 & 2.14 & & 0.996 & 0.322 \\
\hline & USE & 0.05 & 0.089 & 0.062 & 0.558 & 0.578 \\
\hline & INF & 0.237 & 0.107 & 0.252 & 2.213 & 0.029 \\
\hline & SER & 0.353 & 0.091 & 0.407 & 3.886 & $\mathrm{O}$ \\
\hline
\end{tabular}

Berdasarkan Tabel 8, dapat diketahui seberapa besar pengaruh variabel independen terhadap variabel dependennya. Nilai $R$ Square sebesar 0,411, artinya sebesar 41,1 persen variabel usability, information dan service interaction memengaruhi minat beli pada muslimarket.com. Sedangkan sisanya sebesar 59,9 persen dipengaruhi oleh variabel lain diluar dari penelitian ini.

Tabel 8. Nilai Koefisien Determinasi

\begin{tabular}{ccccc}
\hline Model & R & R Square & $\begin{array}{c}\text { Adjusted R } \\
\text { Square }\end{array}$ & $\begin{array}{c}\text { Std. Error of the } \\
\text { Estimate }\end{array}$ \\
\hline 1 & $.641^{\mathrm{a}}$ & 0.411 & 0.393 & 3.08 \\
\hline
\end{tabular}

Namun secara simultan atau bersama-sama, ketiga variabel independen pada penelitian ini, dimana usability, information dan service interaction berpengaruh signifikan terhadap minat beli pada muslimarket.com. dibuktikan dengan hasil uji $\mathrm{F}$ hitung lebih besar dari $\mathrm{F}$ tabel $(22,371>2,70)$. Selengkapnya pada Tabel 9.

Tabel 9. Hasil Analisis Regresi Berganda dengan Uji F

\begin{tabular}{cllccccc}
\hline \multicolumn{2}{l}{ Model } & $\begin{array}{c}\text { Sum of } \\
\text { Squares }\end{array}$ & df & $\begin{array}{l}\text { Mean } \\
\text { Square }\end{array}$ & F & Sig. \\
\hline \multirow{3}{*}{$\mathbf{1}$} & Regression & 636.497 & 3 & $\mathbf{2 1 2 . 1 6 6}$ & $\mathbf{2 2 . 3 7 1}$ & .000 $^{\text {a }}$ \\
\cline { 2 - 7 } & Residual & 910.463 & 96 & 9.484 & & \\
\cline { 2 - 8 } & Total & 1546.96 & 99 & & & \\
\hline
\end{tabular}

Penelitian ini menunjukkan bahwa tinggi-rendahnya minat beli konsumen pada muslimarket dipengaruhi oleh ketiga indikator Webqual 4.0 yaitu usability (kegunaan), information (informasi) dan service interaction (interaksi layanan) secara bersama-sama, seperti yang disediakan oleh muslimarket.com saat ini. Hal ini juga sejalan dengan beberapa penelitian terdahulu (Yuliandi \& Prasetyo, 2012) yang menyatakan bahwa ketiga indikator kualitas website (usability, information dan service interaction) secara simultan berpengaruh signifikan terhadap minat beli pada produk Jaben Bandung. Meskipun memang secara parsial, usability tidak berpengaruh sigifikan terhadap minat beli pada muslimarket.com 
Dengan demikian, berdasarkan hasil penelitian maka muslimarket.com sebagai salah satu e-commerce terlengkap berbasis syariah di Indonesia sebaiknya meningkatkan ketiga indikator Webqual 4.0 yaitu usability (kegunaan), information (informasi) dan service interaction (interaksi layanan) agar minat beli konsumen dalam berbelanja online melalui muslimarket.com juga meningkat. Sedangkan untuk information dan service interaction harus dipertahankan oleh muslimarket.com karena keduanya memang berpengaruh signifikan terhadap minat beli pada muslimarket.com.

\section{KESIMPULAN}

Berdasarkan hasil penelitian dapat disimpulkan bahwa information dan service interaction berpengaruh signifikan terhadap minat beli pada muslimarket.com. Hal tersebut dibuktikan dari nilai t hitung > t tabel masing-masing adalah 2,213 > 1,661 dan 3,386 > 1,661. Dimana hanya usability yang tidak berpengaruh terhadap minat beli pada muslimarket.com yang dibuktikan dengan nilai t hitung $<\mathrm{t}$ tabel $(0,558<1,661)$. Namun secara simultan, ketiga indikator kualitas website (Webqual 4.0) berpengaruh signifikan terhadap minat beli pada muslimarket.com.

\section{DAFTAR PUSTAKA}

Barnes, S dan Vidgen, R. (2002). An Integrative Approach to the Assessment of E-commerce Quality. Journal of Electronic Commerce Research, 3(3): 114-126.

Delone, W. H., dan McLean, E.R. (2003). The DeLone and McLean Model of Information Systems Success: A Ten-Year Update. Journal of Management Information Systems, 19(4):9-30.

Dorothea, Wahyu Ariani. (2004). Pengendalian Kualitas Statistik (Pendekatan Kuantitatif dalam Manajemen Kualitas). Yogyakarta: Andi Ofset.

Ferdinand, Augusty. (2006). Metode Penelitian Manajemen. Semarang: Badan Penerbit Universitas Diponegoro.

Husein, Umar. (2010). Manajemen Riset Pemasaran dan Perilaku Konsumen. Jakarta: Gramedia Pustaka.

Kotler, Philip \& Keller, Kevin Lane. (2012). Marketing Management. England: Pearson Education Limited.

Laudon, K.C \& Carol, G,T. (2009). E-commerce, Business Technology Society. New Jersey: Pearson Prentice Hall.

Hidayat, Rahmat. (2010). Cara Praktis Membangun Webste Gratis: Pengertian Website. Jakarta: Elex Media Komputindo. 
Internet World Stats. (2017). Asia Internet Use, Population Data and Facebook Statistics. Diakses dari https://www.internetworldstats.com/stats3.htm\#asia pada 17 Desember 2017 pukul 16.02 WIB.

Sam, M., Fazli, M. dan Tahir, M.N.H. (2009). Website Quality and Consumer Online Purchase Intention of Air Ticket. International Journal of Basic \& Applied Science IJIBASIJENS, 9(10): 4-9.

Sarwono, Jonathan. (2006). Strategi Penelitian di Internet. Yogyakarta: Graha Ilmu.

Setiawan dan Kusrini, D. E. (2010). Ekonometrika, Yogyakarta: Andi.

Siregar, Syofian. (2014). Statistik Parametrik untuk Penelitian Kuantitatif. Jakarta: Bumi Aksara.

Simamora, Bilson. (2011). Riset Pemasaran. Jakarta: Gramedia Pusataka Utama.

Sugiono dan Susanto, A. (2015). Cara Mudah Belajar SPSS dan Lisrel Teori Dan Aplikasi Untuk Analisis Data Penelitian. Bandung: Alfabeta.

Yamin, S., Rachmach, L.A., Kurniawan, H. (2011). Regresi dan Korelaso dalam Genggaman Anda. Jakarta: Salemba Empat.

Yosi, Nathania. (2017). Pertumbuhan E-commerce Indonesia Meningkat Tajam, Siapa di Posisi Teratas? Diakses dari https://business.idntimes.com/economy/yoshi/pertumbuhan-e-commerceindonesia-1/full pada 17 Desember 2017 pukul 15.47 WIB.

Yuliandi dan Prasetyo, A. (2012). Pengaruh Kualitas Website terhadap Minat Beli Produk Jaben Bandung. Bandung: Telkom University. 
